\title{
Contract Farming of High-Quality Rice in Kampong Speu
}

\author{
Nou Keosothea and Heng Molyaneth
}

\section{INTRODUCTION}

Contract farming is seen as one of the policies to overcome current impediments to commercialisation in the Cambodian rice sector. The Angkor Kasekam Roongroeung Co. Ltd. (AKR) was the first agribusiness firm to implement contract farming of rice, beginning in 1999 with about 100 farmers; it currently claims to have over 50,000 contracted farmers in four provinces (AKM 2015). The approach was later adopted by other development organisations, such as the Cambodian Centre for Study and Development in Agriculture (CEDAC). A study by Cai et al. (2008), for the Asian Development Bank Institute (ADBI), on the impacts of AKR's rice contract farming scheme on farmers' performance provides some useful insights. In general, however, little is known about rice contract farming

N. Keosothea $(\triangle)$

National Committee, Economic and Social Commission for Asia and the Pacific, Ministry of Foreign Affairs and International Cooperation, Phnom Penh, Cambodia

H. Molyaneth

Faculty of Development Studies, Royal University of Phnom Penh, Phnom Penh, Cambodia

(C) The Author(s) 2020

R. Cramb (ed.), White Gold: The Commercialisation of Rice

Farming in the Lower Mekong Basin, https://doi.org/10.1007/978-981-15-0998-8_16 
in Cambodia in terms of its contractual arrangements, inclusiveness, benefits, and challenges.

To help fill the knowledge gap, this study aimed to examine three aspects of AKR's rice contract farming: (a) inclusion of smallholder farmers and contractual arrangements, (b) benefits of contract farming for farmers, and (c) challenges faced by farmers and agribusiness firms. AKR was selected as a case study because the company operates the largest scale of rice contract farming in Cambodia. Findings of this study will hopefully contribute to policymaking on how to make rice contract farming more developmental. In this chapter, we first review the existing literature on the effects of contract farming, then outline the methods used in the study. This is followed by a presentation of research findings on the inclusion of smallholders, the nature of the contractual arrangements, and the benefits and challenges of contract farming, and a discussion of policy options based on these findings. A summing-up concludes the chapter.

\section{Understanding the Effects of Contract Farming}

Although one of the purported benefits of contract farming is to help smallholder farmers integrate into global agri-food supply chains, smallholders have not always been included because working with them incurs high transaction costs and a high risk of producer defaults (Key and Runsten 1999). On the other hand, smallholders are preferred in some cases to minimise the negative effects of crop failure, enable a flexible production portfolio, enhance the quality of produce, and reduce the dropout rate of members (Birthal et al. 2005). The experience of various contract farming schemes in Thailand suggests that, where production requires large amounts of capital, medium- and large-scale farmers are chosen; but when hard work and commitment are more important, smallscale farmers have a better chance to participate (Sriboonchitta and Wiboonpoongse 2008).

Findings on the effects of contract farming on farmers and agribusiness firms are mixed and inconclusive. Farmers might enjoy some benefitsincreased profitability and income; better access to production inputs such as machinery, seeds, fertilisers, infrastructure, and credit; a guaranteed and stable price; a reliable and secure market; and improved technical farm management skills (Setboonsarng et al. 2005). At the same time, they can experience losses due to the failure of agribusiness firms to comply with agreed terms and conditions of the contract, whether intentionally or 
unintentionally. The benefits could also be negatively affected by the farmers' limited ability to apply required farming technology, resulting in failing to attain defined levels of productivity and quality. Moreover, farmers could be in debt because of their over-reliance on easily accessible credit provided by the contracting agribusiness firm.

Agribusiness firms can similarly have both positive and negative experiences. On the positive side, they could secure sources of supply with required quality and standards, reduce production and transaction costs, transfer production risks to farmers, and get more agricultural support from government, such as credit and subsidies. On the other hand, some firms experience losses because farmers break the contract by selling to third parties when the price increases. This practice of extra-contractual marketing is an often-reported problem facing agribusiness firms involved in contract farming schemes.

\section{Research Methods}

The study was based on interviews with key informants in Kampong Speu Province over two periods: May 2012 and June 2013. According to Cai et al. (2008), more than $80 \%$ of contract farmers were in Kampong Speu Province. All but two interviewees were from Prey Khmeng Commune and Chom Sangker Commune in Phnom Srouch District. This district was an ideal site for the study due to AKR Company's long history there. A total of 20 key informants were interviewed-ten farmers, four village heads, one commune clerk, three staff of the Society for Community Development in Cambodia (SOFDEC), a local NGO, and two staff of the AKR Company (whose office was in Angsnoul District). Farmer interviewees were selected through snowball sampling with the support of SOFDEC staff. Since village heads were also farmers, a total of 14 farmers were interviewed, comprising 11 former contract farmers, 2 current contract farmers, and 1 non-contract farmer. All farmers interviewed cultivated a single crop of rainfed rice in the wet season.

All interviews were done in a semi-structured manner. There were four different interview guides-for farmers, representatives of the commune association, the staff of the local NGO, and representatives of the AKR Company. Some common questions were asked of former contract farmers, current contract farmers, and non-contract farmers, but there were also specific questions for each type of farmer. All interview guides covered reasons why farmers and agribusiness firms cooperated under a contract, 
and the terms and conditions, costs and benefits, and challenges of working under a contract.

\section{INCLUSION OF SMALLHOLDERS}

AKR considered several factors in deciding where to start contract farming in the early stages of its operation. The foremost factor was the agronomic conditions. The company started with Pkar Malis (a type of aromatic rice), a variety that is selective in terms of agronomic conditions. AKR had examined agronomic conditions in several provinces and chose four to start its rice contract farming: Kampong Speu, Kandal, Takeo, and Kampot. Agronomic conditions remained a critical factor when deciding on the specific locations within the province. Not all communes, villages, and households had the conditions suitable for Pkar Malis rice, hence some were excluded from the contract farming scheme from the outset.

Another criterion for selecting villages was the degree of concentration of interested farmers. Due to a strong requirement for varietal purity, villages having interested farmers who were geographically dispersed were not eligible for the contract. AKR staff interviewees explained that when Pkar Malis rice is grown next to other varieties, pollen of other rice varieties can reduce the varietal purity of the Pkar Malis. To avoid this, AKR only selected villages where many farmers were interested in participating in contract farming and farmed close together.

The size of landholding was not a condition for selecting farmers when the company began its operation. Nevertheless, in 2000, the share of farmers contracted with less than a hectare of land was only about $5 \%$ of AKR's total number of contracted farmers. Three main reasons explain this low representation of very small holdings. First, very poor farmers could not spare their land for the production of commercial rice. Second, even if they wanted to join the scheme, if their agronomic conditions were not suitable, the company did not accept them. Third, in some cases, farmers had a large area of land but the land that could successfully grow Pkar Malis rice was less than a hectare, hence the company only accepted the suitable land.

A minimum of one hectare of suitable land was enforced after a few years of operation because the company found it difficult to work with farmers owning less than this. Often the urgent need for money had forced poorer farmers to sell their rice to informal traders at the farm gate. Sometimes farmers consumed all the grain produced. Even with these 
breaches of contract, the company could not take measures against the farmers because they were too poor to be held responsible for their actions. Therefore, despite a few exceptions, the company decided to exclude farmers with less than a hectare of land. Exceptional farmers were those who were committed to the company, hardworking, and strongly recommended by village heads.

A subsequent significant change in the buying policy of AKR made the area of land an irrelevant condition. Due to some challenges (see below), AKR changed the policy of buying rice from individual farmers to buying collectively from each village. As long as farmers had rice to sell to AKR, they could sell through the village, regardless of farm size. Data from interviews with all the four village heads confirmed this practice. Such collective purchase prevented the company from knowing the extent of participation of very small-scale farmers in their contract farming scheme.

\section{Contractual Arrangements}

In order to gain villagers' trust and as a more efficient way to manage contract farming, AKR established "commune associations". Each association comprised the head and deputy head of the commune and the village heads. The associations had various roles, beginning with helping AKR persuade and select the contract farmers. After one year of attempting to introduce the concept of contract farming directly to farmers, the company realised that it was difficult to gain farmers' trust in this way. This led them to seek the support of the local authority at commune and village levels in explaining the idea to farmers. Commune associations then assisted AKR in evaluating the suitability of farmers in terms of their agronomic conditions and commitment. The company delivered quality seeds and technical advice to contracted farmers through these associations. During the production stage, commune associations were obliged to monitor their contracted members and report to AKR on the production process, progress, and challenges. In exchange for the services of the commune associations, AKR provided incentives to the commune and village heads at the rate of KHR 30 and 40, respectively, for each kilogramme of rice sold by members of their association.

The "resource-providing" type of contract adopted by AKR seems to have worked well in the Cambodian context, where the market for farm inputs remains underdeveloped. Farmers in general often faced problems of limited access to necessary production inputs such as seeds, fertilisers, 
credit, and extension services. They also had difficulty selling their products in markets at reasonable prices. By signing a contract with AKR, farmers had access to quality seeds, extension services, a secure market, and competitive prices. The company advanced seed to farmers without interest.

However, the contract was not prepared in a participatory manner. The company drafted the contract and asked farmers to sign it. AKR and members of the commune association held a village meeting to explain the concept of contract farming and the terms and conditions of the contract to farmers. Village heads recorded the names of interested farmers and, together with AKR's technical team, examined their agronomic conditions. If the land was suitable, the company invited farmers to its office and explained the contract again to ensure farmers' proper understanding before having them sign the contract.

Although the contract specified a number of necessary clauses, it lacked several important aspects. It mentioned the amount of seed borrowed by farmers but did not indicate whether the company would provide seed to farmers every year. It described the obligations of AKR to provide contract farmers with fees for transporting paddy rice to the company and to pay members of the commune associations for their services. It also included conditions under which the company would buy paddy rice from farmers. The penalty clause specified the consequences for farmers who breached the contract but stated nothing about the consequences for the company if it was to breach the contract. The contract failed to mention the date on which farmers needed to return the seed, the duration of the contract, and how each party could end the contract.

\section{Benefits of Contract Farming}

\section{Access to Market}

Access to an export market with a competitive price was the first and most important reason why farmers were interested in joining the contract farming scheme and was the major expected benefit for their participation. The price provided by AKR was competitive in two ways. First, it was much higher than the prices for ordinary varieties grown by farmers before AKR came. In 1999, the market for Pkar Malis rice had not been developed in Phnom Srouch District. Farmers grew ordinary varieties for household consumption. When in urgent need of money, farmers sold their paddy rice for KHR 200-300 per $\mathrm{kg}$. The AKR was the first to 
introduce Pkar Malis to farmers and the buying price was KHR 500-700 per $\mathrm{kg}$. Second, the price was competitive when compared to the price offered by informal traders for the same type of rice. After the market of Pkar Malis rice was established, traders and CEDAC also bought this variety. However, AKR always bought rice from contract members at a higher price than other buyers.

With a well-established market for the Pkar Malis variety, contract farmers saw the importance of the price provided by AKR less in terms of its value and more in terms of insurance. AKR's higher price came with many production challenges (see below), which lessened its attraction for some farmers. Others, however, maintained their relationship with AKR or CEDAC, despite the production challenges, in order to keep reaping the benefit of the consistently high market price.

\section{Access to Quality Seeds}

The second most important benefit was access to quality seeds. Although CEDAC also bought Pkar Malis rice, it did not follow AKR's policy to advance quality seeds to farmers. Farmers increasingly appreciated this benefit. Information from interviews with former AKR contract farmers suggested that, in the early phase of contract farming when rice farming was only for the domestic market and household consumption, farmers cared less about the varietal purity of harvested paddy rice. Their main reason for participating in the contract farming scheme of either AKR or CEDAC was the access to markets with a competitive price provided by the two institutions. With the establishment of an export market, farmers were more concerned about the availability of quality seeds as a primary reason for contracting to supply AKR. These seeds produced high yields with excellent varietal purity, which was one of the conditions of the highend export markets.

A current AKR contract farmer explained that, although she had already joined the contract farming scheme of CEDAC, she still contracted with AKR to receive new quality seeds because her old seeds were no longer pure after several years of farming. A village head related that, in 2006, only 30 out of 159 households in the village expressed their interest in contract farming with AKR because they had not realised the necessity of quality seed. By 2011, 98 households had registered with AKR to obtain new foundation seed, but the company did not advance seed to them. 


\section{Access to Technology}

The third benefit of contract farming with AKR was access to quality extension services. In order for farmers to produce grain with the required standards in terms of varietal purity and yield, AKR delivered training and ongoing technical support to its contracted farmers. However, the company did not exclusively provide this benefit because CEDAC and SOFDEC also offered extension services to farmers.

AKR only delivered training on production techniques to its members during the first year of contract farming. The company trained members of commune associations who would further train their contract farmers. The content of the training covered the whole production process. The benefits of the training seem to have continued even after the termination of contract farming. For example, a former contract farmer of AKR appreciated the training since he could apply the production technology when he grew other rice varieties after quitting the AKR scheme.

\section{Access to Credit and Other Benefits}

Despite their irregular provision, other secondary benefits received from AKR included access to credit with a low interest rate, fees for the services provided by the commune associations, fees for transporting rice to the AKR office, and the use of trustworthy scales to weigh their crop.

The company originally provided loans to its members without interest, but the policy at the time of the study was to charge $1.4 \%$ per month. This compares with an average monthly interest rate charged by microfinance institutions in Cambodia of around 3\% for loans in riels (see Chap. 15). ${ }^{1}$ In 2011, the company gave loans to about 500 households.

In terms of the fee for the services of the commune association, AKR was not consistent in issuing this payment as stipulated in the contract. Only in the early stages of the operation did it pay the associations, although they were still working for the company by collecting paddy rice from farmers.

AKR also did not consistently pay farmers the transportation fee as stated in the contract, supposedly because of the varying volumes delivered. When farmers had low yields, they were not able to sell the required amount, resulting in the company not being able to fulfil its export orders. This loss was partly made good by withholding transport fees.

Finally, farmers pointed out that AKR used reliable and trustworthy scales when weighing their paddy rice. This was another benefit compared 
Table 16.1 Estimated costs and returns for a one-hectare rice farm, by type of farmer

\begin{tabular}{lccc}
\hline & $\begin{array}{l}\text { Former contract } \\
\text { farmer }\end{array}$ & $\begin{array}{l}\text { Current contract } \\
\text { farmer }\end{array}$ & $\begin{array}{l}\text { Non-contract } \\
\text { farmer }\end{array}$ \\
\hline Yield (kg/ha) & 2500 & 2000 & 2000 \\
Price (KHR/kg) & 1350 & 1450 & 1350 \\
Gross revenue (KHR/ha) & $3,375,000$ & $2,900,000$ & $2,700,000$ \\
Variable costs (KHR/ha) & $1,230,000$ & 986,000 & $1,000,000$ \\
Gross margin $(\mathrm{KHR} / \mathrm{ha})$ & $2,145,000$ & $1,914,000$ & $1,700,000$ \\
\hline
\end{tabular}

Source: Interviews with key informants

with selling to local traders, who not only offered a lower price but, farmers claimed, always under-weighed their paddy using doctored scales.

\section{Increased Profit}

The above-mentioned benefits enabled contract farmers to increase their profit from rice farming. Based on information provided in the interviews, with a yield of $2 \mathrm{t} / \mathrm{ha}$, contract farmers could generate a gross revenue of around KHR 2.9 million per ha, which was lower than the former contract farmers' KHR 3.4 million per ha but moderately higher than non-contract farmers' KHR 2.7 million per ha (Table 16.1). The same ranking was observed in gross margin per ha, with former contract farmers netting KHR 2.1 million, contract farmers KHR 1.9 million, and non-contract farmers KHR 1.7 million. This finding confirms the estimates given by Cai et al. (2008). The implication is that entering into contract farming increases the profitability of rice farming, but that farmers who "move on" from contract farming achieve even higher returns.

\section{Challenges of Contract Farming}

Contract farming can be regarded as successful when the agribusiness firm and the contracted farmers are both satisfied with the benefits they receive and thus maintain their business relationship. The lower revenue and gross margin of contract farmers compared to former contract farmers suggest that there were problems with the contract farming scheme in this case that made it less profitable, resulting in farmers withdrawing. The interviews provided insights into the challenges faced, how these were addressed, and the support still needed. 


\section{High Requirement for Varietal Purity}

One of the great challenges was the requirement for high varietal purity of the paddy rice produced. Farmer interviewees expressed different attitudes towards the difficulties inherent in the purification process. Some former AKR contract farmers raised the purification problem as one of the main reasons they left the scheme, despite the high price. However, some current farmers did not see the requirement as too difficult to meet, just needing some extra effort on their part. The policy of AKR specified that paddy rice had imperfect varietal purity if there were three or more grains of the wrong variety in every 100 sample grains. Different levels of varietal purity were reflected in the different prices that farmers received. Thus, contract farmers ran the risk of receiving a lower price if they had not made enough effort in purification. Some contract farmers avoided the challenge by leaving the AKR contract farming scheme. Although informal traders offered a lower price, they attached no conditions to their purchase.

AKR started contract farming to fulfil export requirements in terms of quality and quantity. Varietal purity was one of the quality criteria, especially for the high-end market. The company did not consider the requirement too high for contract farmers. Instead, they attributed the inability to fulfil this condition to farmers' low commitment. Such attribution resulted in selective discontinuity in the business relationship between $\mathrm{AKR}$ and contract farmers. To maintain high varietal purity, AKR changed the improved foundation seed for their contract members every two to three years. The company based the decision to distribute new foundation seed on the farmer's past purity levels.

\section{Strict Requirement of Moisture Level}

AKR contract farmers faced a problem with drying their paddy. One of the contract conditions was that paddy rice had to have a moisture level less than $16 \%$. The company trained its contracted farmers on how to measure the moisture level, but it was not easy for farmers to dry their paddy rice to the required level due to unfavourable weather conditions and their reliance on sun-drying. Former and current contract farmers explained that, to get down to $16 \%$ moisture, they needed to dry their paddy for about two consecutive days under the hot sun, but sun-drying was unreliable. If the dried grains were exposed to rain, they were likely to germinate, yellow, or rot. 
AKR accepted paddy rice with a slightly higher moisture level than required but reduced its price accordingly. Farmers did their own mental calculation and reported that sometimes it was not profitable to sell to AKR. They felt that, no matter how hard they tried, the company could reduce the price due to imperfect varietal purity and/or excess moisture. Former contract farmers preferred selling their paddy rice to informal traders, who put no conditions on their purchase. Instead of purifying and drying paddy, former contract farmers chose to spend their time on other income-generating activities.

The strict requirement for moisture level posed a difficulty not only for the farmers but also for the company. The AKR staff observed that the company was successful in contract farming in terms of price but not in terms of flexibility when compared to informal traders. The company was able to pay a higher price, but contract farmers needed to produce very pure and dry paddy rice. Since the company operated on a very large scale, it was unable to buy wet paddy rice from farmers and sun-dry it in its facilities. Unlike the company, informal traders could buy wet paddy and dry it themselves in local drying yards. Given their credit constraints, farmers were inclined to sell to informal traders right after harvesting without any drying.

Farmers' inability to fulfil the moisture requirement had resulted in AKR not being able to satisfy export demand. To meet its export orders, the company had resorted to buying paddy from other sources. All sellers had to fulfil the requirements of purity and moisture level, though to different degrees and for different prices. Current contract farmers received the highest price because the quality of their paddy was also the highest (Table 16.1). At the time of the study, the company bought about $60 \%$ of its exported volume from traders because it could not get enough paddy from its farmers. Due to insufficient capital, AKR was not able to get to the root of the problem of unfilled export orders. The company realised that, if it could buy wet paddy from farmers and dry it, it would be able to collect larger quantities of paddy. However, acquiring high-capacity drying machines was beyond the company's financial capacity.

\section{Limited Access to High-Quality Seed}

Another challenge for contract farmers and a factor affecting low varietal purity was limited access to high-quality seed. New quality seed could produce higher and purer yields, with the capacity to retain seed for the 
next two to three crop seasons. The continued use of retained seed beyond this period would result in lower yields and mixed varieties. AKR was the first and only agribusiness firm to advance quality seed to their contract farmers without interest. Current contract farmers in one of the selected villages expressed concern about the purity of their retained seed stocks. AKR had provided quality seed of Angkong Seouy to them in 2010 and they had already used their retained seed stocks in 2011 and 2012. As the company had not provided new seed for them in 2013, they continued to use their retained seed for another year, despite running the risk of lower yield and producing mixed varieties.

Farmers adopted diverse strategies to deal with the shortage of highquality seed. Some non-contract farmers turned to AKR for new seed, but they were disappointed because the company advanced seed neither to them nor to the current contract farmers in 2013. Some former AKR contract farmers and current and former contract farmers with CEDAC were willing to join SOFDEC to obtain new seed of the Pkar Roumdoulvariety. However, the seed provision scheme of SOFDEC had only just started in the year of the study, and the variety provided was not one that was purchased by AKR or CEDAC. Moreover, the scheme was not large enough to cover all farmers, resulting in a considerable number missing out, and in any case, SOFDEC only advanced seed to farmers but did not contract to buy the harvested rice.

The staff of AKR raised farmers' low commitment to the company as a reason why the company could not continue to provide quality seed to all participants. The company advanced seed to all its contract farmers in 2000 and 2001, but it was no longer the practice. The staff observed that, due to both drought and lack of commitment, contract farmers could not produce high yields of sufficient purity, causing the company a great loss. Learning from this experience, the company advanced seed only to a few communes whose farmers were committed to the company.

\section{Breaches of Contract}

Ordinary contract farmers and contract farmers who were also members of commune associations suffered from AKR's irregular payment for transportation of paddy to the company and for the services of the associations. As mentioned above, the contract specified that AKR would pay these fees. In reality, this was not consistently implemented, resulting in participating farmers losing some of their expected revenue from selling rice to 
AKR. Also, despite its promise to pay each commune and village head KHR 30 and KHR 40, respectively, for every kilogramme of paddy sold by their members, the company only occasionally adhered to this commitment. Even though the contract was legally binding, farmers had no ability to hold the company accountable.

A long-standing problem for AKR was the extra-contractual marketing undertaken by contracted farmers. AKR staff explained that the company knew if farmers broke their contracts in this way but was not able to take any measures against them in the way commercial banks or microfinance institutions could. Interviews with contract farmers revealed that none had been fined for extra-contractual marketing. The only solution the company saw was to explain to farmers the costs and benefits of selling paddy to the company and to traders.

Another example of contract breach by farmers was the misuse of their membership cards. There were reports that some farmers had rented their membership card to traders or other non-contract farmers, enabling them to sell paddy to the company at the highest price. As noted above, the company did buy from other sources but reserved the best price for holders of current cards. A former AKR contract farmer complained that he and other farmers still wanted to continue with contract farming since it improved his livelihood, but the company had already withdrawn from his village. He suspected this was due to some farmers in the village engaging in this practice of renting out their cards.

\section{Credit Constraints}

Credit constraints represented a serious challenge for both contract farmers and AKR. Farmers with credit constraints were under pressure to sell their paddy quickly to informal traders or were not willing to sell paddy to AKR on credit (i.e., with delayed payment). This contributed to farmers' extracontractual marketing. Informal traders made selling to them convenient for farmers by not placing any conditions in terms of moisture content or varietal purity and by paying farmers immediately. On the other hand, AKR used to buy from their contract farmers on credit, resulting in a large number of farmers quitting the scheme. The company was able to improve its financial position in 2010 and paid cash on delivery to its current members, but it was unknown whether the company could sustain this practice.

In addition to its past inability to pay contract farmers immediately, credit constraints prevented AKR from investing in large-scale paddy driers. Acquiring high-capacity driers would have significantly improved the 
company's ability to purchase wet paddy rice from farmers, increasing their export volume and making life easier for their contract farmers.

\section{Rainfall Variability}

Variability in rainfall during the growing season had a direct negative impact on contract farmers and an indirect negative impact on AKR. When drought affected their crop, farmers could not produce a high yield, resulting in their inability to supply the amount of rice stipulated in their contract. For example, in one of the study villages, contract farmers were not able to sell any surplus rice to AKR in 2011 and 2012 due to drought.

The AKR staff reported frequent losses due to drought. In the early years of their operation, the company experienced dramatic losses since farmers could not return the advanced seed, which was very expensive. The company terminated contracts with several communes because of drought. Despite otherwise favourable agronomic conditions, the company still withdrew because the communes were drought-prone.

\section{Policy Options for Contract Farming}

\section{Raising Awareness}

Raising farmers' awareness of the costs and benefits of contract farming could help increase their commitment to the company. As the study revealed, one of the conditions that AKR considered when terminating contracts with any village was the overall level of commitment of the farmers in that village. On the other hand, despite their limited landholdings, the poorest farmers could participate in the contract farming scheme as long as they were highly committed to the policies of the company. The Ministry of Agriculture, Forestry and Fisheries (MAFF) could provide education on weighing up the costs and benefits of participating through its extension service, or make use of existing commune associations created by the AKR to conduct the training. Such intervention would need to take the stance of an independent adviser, however, to avoid seeming to persuade or coerce farmers to enter into contracts reluctantly.

\section{Rice-Drying Technology}

Removing technical constraints for paddy drying would create more benefits for both parties. One possible measure is to improve farmers' knowl- 
edge of new drying technology. The MAFF could collaborate with the International Rice Research Institute (IRRI) which has been working in Cambodia on adaptive technology to deal with post-harvest losses, including paddy drying. Farmer representatives could also attend a training course on agricultural mechanisation at the Don Bosco Technical School, which has received technical assistance from IRRI. However, in general, small-scale village-based driers have not been successful.

Another possible measure is to encourage the private sector, for example rice millers, to invest in drying technology. According to the 2013 report of an ADB-IRRI training course, only a large-scale rice miller and a farmer cooperative had so far provided drying services to farmers in Cambodia. ${ }^{2}$ This practice needs to be expanded to reach farmers across the country.

Yet another measure would be to provide agricultural credit to AKR directly to invest in high-capacity drying machines. AKR would be able to buy a larger volume of wet paddy rice from farmers if the company had such drying capacity. Hence, there may well be a business case for financing this investment.

\section{High-Quality Seed}

Improving farmers' access to high-quality seed could be achieved by accelerating the implementation of the current rice policy. High-quality seed determines the production volume as well as the quality, including the level of varietal purity. The government has already included this issue as a "quick-win" measure in its policy paper, The Promotion of Paddy Production and Rice Export (RGC 2010). The implementation of this seed policy was observed during fieldwork. However, the varieties distributed by the local authority, for example Sen Pidor and Chulsar, were for household consumption rather than for commercial purposes. As a policy measure, the government could coordinate with rice exporters on the varieties to be exported and distribute seed accordingly.

\section{Access to Credit}

Due to credit constraints, farmers could not store their paddy long enough to sell to AKR or CEDAC for high prices, or survive the subsequent waiting period until receiving payment. The urgent need for cash pushed farmers to engage in extra-contractual marketing, undermining the viabil- 
ity of the contract farming scheme. Improving farmers' access to credit should be able to reduce this extra-contractual marketing. On the other hand, increasing access to credit for agribusiness firms could help overcome their current capital constraint to paying farmers on time (for paddy delivered as well as service fees) and investing in drying equipment. The above-mentioned policy paper specifies measures to alleviate the credit constraints facing farmers and agribusiness firms, mainly through the expansion of microfinance institutions (see Chap. 15). However, there may be a need for an Agricultural Bank as in Thailand to increase the flow of credit for profitable investments for farmers and the agribusiness sector.

\section{Contract Enforcement}

The study found that contract farmers and AKR both experienced breaches of contract but were unable to take any legal measures. There was no institution to oversee compliance with the contract on the part of both parties. MAFF could consider implementing Article 7 of Chapter 2 of the SubDecree on Contract Farming regarding the establishment of a coordination committee. As stipulated in the Sub-Decree, the Coordination Committee for Agricultural Production Contracts (CCAPC) "shall intervene or reconcile arguments or conflicts that might occur from the implementation of the contract farming". While the Sub-Decree indicates that the CCAPC would function at the national level, the government should consider establishing provincial-level committees for easier access by farmers.

\section{Conclusion}

The study found that the rice contract farming scheme of Angkor Kasekam Roongroeung Co. Ltd. (AKR) was inclusive of poor farmers with small farms, even those with less than a hectare. With access to several important benefits of the scheme, contract farmers were able to increase their returns from rice farming. However, some flaws in the contractual arrangements and the requirement to deliver high-quality rice for the export market posed a number of challenges to both AKR and the participating farmers, some of which could be addressed through policy interventions. Overcoming these challenges will enhance the benefits of contract farming for both farmers and agribusiness firms and thus contribute to further commercialisation of the rice sector and rural poverty reduction. 


\section{Notes}

1. MFTRANSPARENCY Case Study on Lending Interest Rate in Cambodia. Available at http://www.mftransparency.org/wp-content/uploads/2012/ 05/MFT-BRF-302-EN-Outlawing-Flat-Interest-in-Cambodia-2011-10. pdf (accessed 5 July 2013).

2. Cambodia: Postharvest project assesses outcomes. Available at http://irrinews.blogspot.com/2013/06/cambodia-postharvest-project-assesses.html (accessed on 17 July 2013).

\section{REFERENCES}

AKM, 2015. Angkor Rice website. Available at http://angkorrice.com/farmermember/ (viewed 23 June 2017).

Birthal, P. S., Joshi, P. K., and Gulati, A., 2005. Vertical Coordination in HighValue Food Commodities: Implications for Smallholders. MTID Discussion Paper No. 85. Washington DC: International Food Policy Research Institute (IFPRI).

Cai, J., Ung, L., Setboonsarng, S., and Leung, P., 2008. Rice Contract Farming in Cambodia: Empowering Farmers to Move beyond the Contract toward Independence. ADBI Discussion Paper 109. Tokyo: Asian Development Bank Institute (ADBI).

Key, N., and Runsten, D., 1999. Contract farming, smallholders, and rural development in Latin America: the organization of agroprocessing firms and the scale of outgrower production. World Development 27(2): 381-401.

Royal Government of Cambodia (RGC), 2010. Policy Paper on the Promotion of Paddy Production and Rice Export. Phnom Penh: Council of Ministers.

Setboonsarng, S., Leung, P., and Cai, J., 2005. Contract Farming and Poverty Reduction: A Case of Organic Rice Contract Farming in Thailand. Tokyo: Asian Development Bank Institute (ADBI).

Sriboonchitta, S., and Wiboonpoongse, A., 2008. Overview of Contract Farming in Thailand: Lessons Learned. ADB Institute Discussion Paper No. 112. Tokyo: Asian Development Bank Institute (ADBI). 
Open Access This chapter is licensed under the terms of the Creative Commons Attribution 4.0 International License (http://creativecommons.org/licenses/ by $/ 4.0 /$ ), which permits use, sharing, adaptation, distribution and reproduction in any medium or format, as long as you give appropriate credit to the original author(s) and the source, provide a link to the Creative Commons licence and indicate if changes were made.

The images or other third party material in this chapter are included in the chapter's Creative Commons licence, unless indicated otherwise in a credit line to the material. If material is not included in the chapter's Creative Commons licence and your intended use is not permitted by statutory regulation or exceeds the permitted use, you will need to obtain permission directly from the copyright holder.

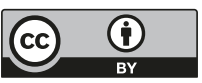

